\title{
AGGREGATE INCOME AND LABOR FORCE PARTICIPATION OF THE AGED
}

\author{
JUANITA M. KREPS*
}

\section{INTRODUCTION}

The low income position of the aged ${ }^{1}$ has aroused a great deal of attention during the past decade. In the analyses of their economic plight, money incomes of individuals ${ }^{2}$ and families ${ }^{3}$ have been reviewed, and the asset position of the aged,

* A.B. 1942, Berea College; M.A. 1944, Ph.D. 1948, Duke University. Assistant Professor of Economies, Duke University. Visiting Bryan Professor of Finance, Woman's College, University of North Carolina, Spring 1962 .

${ }^{1}$ As used herein, "aged" refers to persons aged 65 or older.

2 The low income status of aged individuals and families headed by aged persons is revealed by U. S. Bureau of the Census data for 1960 . In that year, $52.7 \%$ of the noninstitutionalized persons aged 65 and over had less than $\$ 1,000$ money income; $23.7 \%$ had $\$ 1,000$ to $\$ 2,000 ; 10.2 \%$ had $\$ 2,000$ to $\$ 3,000$; only $13.5 \%$ had $\$ 3,000$ or more. The median income for all aged persons was $\$ 950$; the median for income recipients was $\$ 1,150$. For aged men, the 1960 median income was $\$ 1,620$, with more than one-fourth receiving less than $\$ 1,000$. For women aged 65 and over the median was only $\$ 640$, almost three-fourths of the women receiving less than $\$ 1,000$. See Epstein, Sources and Size of Money Income of the Aged, Soc. Sec. Bull., Jan. I962, p. 16, and U. S. Buresu on the Census, Dep't of Commerce, Current Population Reports, Consumer Income ser. P-60, No. 37, at 10-i I (I962).

${ }^{3}$ The median income for families headed by persons aged 65 and over was $\$ 2,900$ (as compared with a median of $\$ 5,900$ for families headed by persons under 65 years of age). Almost one-thind of the families with aged head (but only one-tenth of the families with younger heads) received incomes of less than $\$ 2,000$. At the higher income levels there is also a marked contrast: $16.4 \%$ of the families with aged head, as compared with $37.1 \%$ of the families with younger heads received $\$ 7,000$ or more.

Conclusions as to the comparative living standards provided by the incomes of families with different aged heads have in the past been diffeult, since family size is not uniform, and since the income data have not been classified by family size. The I 960 Census data, however, make it possible to compare family income by age of head and family size. As indicated in the table below, the income

TOTAL MONEY INCOME OF FAMILIES WITH HEAD AGED 65 AND OVER AND HEAD UNDER AGE 65, BY SIZE OF FAMILY, I960

(Noninstitutional Population of the United States)

\begin{tabular}{|c|c|c|c|c|c|}
\hline \multirow[b]{2}{*}{ Characteristic } & \multicolumn{5}{|c|}{ Families Containino- } \\
\hline & All families & 2 persons & 3 persons & 1 persons & $\begin{array}{c}5 \text { or more } \\
\text { persons }\end{array}$ \\
\hline 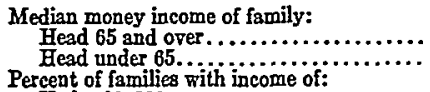 & $\begin{array}{r}\$ 2,897 \\
5,905\end{array}$ & $\begin{array}{r}\$ 2,530 \\
5,314\end{array}$ & $\underset{64,930}{\$ 4}$ & $\begin{array}{l}\$ 6,100 \\
6,300\end{array}$ & $\begin{array}{l}\$ 5,727 \\
8,074\end{array}$ \\
\hline 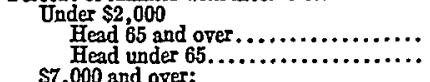 & $\begin{array}{l}31.4 \\
10.2\end{array}$ & $\begin{array}{l}35.7 \\
16.0\end{array}$ & $\begin{array}{r}20.3 \\
9.0\end{array}$ & $\begin{array}{r}17.6 \\
6.6\end{array}$ & $\begin{array}{r}17.9 \\
8.9\end{array}$ \\
\hline 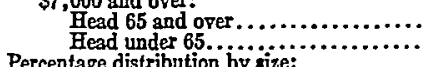 & $\begin{array}{l}16.4 \\
37.1\end{array}$ & $\begin{array}{l}11.5 \\
31.1\end{array}$ & $\begin{array}{l}23.5 \\
37.8\end{array}$ & $\begin{array}{l}41.4 \\
41.0\end{array}$ & $\begin{array}{l}37.9 \\
38.8\end{array}$ \\
\hline 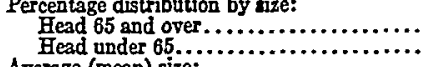 & $\begin{array}{l}100.0 \\
100.0\end{array}$ & $\begin{array}{l}72.8 \\
26.4\end{array}$ & $\begin{array}{l}16.4 \\
21.6\end{array}$ & $\begin{array}{r}5.1 \\
22.9\end{array}$ & $\begin{array}{r}6.6 \\
28.1\end{array}$ \\
\hline 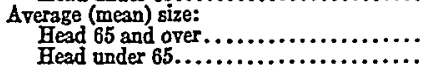 & $\begin{array}{l}2.5 \\
3.9\end{array}$ & $\begin{array}{l}2.0 \\
2.0\end{array}$ & $\begin{array}{l}3.0 \\
3.0\end{array}$ & $\begin{array}{l}4.0 \\
4.0\end{array}$ & 0.4 \\
\hline
\end{tabular}

Source: Epstein, Sources and Size of Lfoney Income of the Aged, Soc. Sec. Bull. Jan. 1962 p. 16. 
frequently cited as an important offset to their unfavorable income position, ${ }^{4}$ has been described. In aggregate terms, the income going to the aged during the r950's reflected two opposing trends: a continued decline in the labor-force participation rates of older men, which caused many incomes to drop sharply, and an expansion in old-age, survivors and disability insurance (OASDI) coverage and benefits, which guaranteed a minimum retirement income to a large proportion of the aged. ${ }^{5}$

The first part of this study is concerned with the sources of income accruing to older persons, and with the changes which have occurred in the proportion of income derived from different sources. In explaining these changes in income composition, the second section analyzes the secular decline in the labor-force participation rates of older men. Finally, the study focuses attention on the question of older men's future labor-force participation rates in the context of the probable aggregate demand for labor.

\section{Composition of the Income of the Aged}

The aggregate income of persons aged 65 and over was estimated to be between accruing to families with aged head typically supports two people; almost three-fourths of the family with older heads consist of two people, whereas slightly over one-fourth of the younger families have only two persons. The median income for two-person families with aged head was about half that for two-person families headed by younger persons. In explaining this wide difference, it has been noted that the two-person families with older heads consist largely of older married couples in which neither husband nor wife work. The disparity between median income of families with aged heads and that of families with younger heads declined as family size (and the chances of one or more members of the older family being in the labor force) increased. For the three-person family the median for the older group was about $70 \%$ as high as the median for younger families, while no significant differences appeared in the families of larger sizes. For each family size, however, the proportion of older families reporting under $\$ 2,000$ was at least twice as high as the proportion of younger families. See U. S. Bureau of the Census, Dep't of Commerce, Current Population Reports, Consumer Income ser. P-60, No. 37, at 5-II (I962); Epstein, Sources and Size of Money Income of the Aged, Soc. Sec. Bull., Jan. 1962, pp. 12-17, 35 .

'Liquid asset holdings of spending units (defined as "all persons living in the same dwelling and related by blood, marriage, or adoption, who pool their incomes to meet major expenses"), as reported by the Federal Reserve Board Survey of Consumer Finances in early 1959, can be summarized as follows: Of the 8 million spending units with head aged 65 or more, $29 \%$ had no liquid assets (U. S. savings bonds, checking and saving accounts in banks, shares in saving and loan associations and credit unions); $17 \%$ had $\$ 500$ or less; $21 \%$ had $\$ 500$ to $\$ 2,000 ; 33 \%$ had $\$ 2,000$ or more. The median liquid asset value for all spending units with an aged head was just over $\$ 700$; the median for all spending units with aged head with holdings was about \$I,800. Among the spending units with aged heads, low liquid asset ownership was correlated closely with low income.

Equity in a home represents the major portion of older people's net worth. In 1959, two-thirds of all nonfarm families with head aged $6_{5}$ or over owned their homes, $83 \%$ of these homes being free of mortgage debt. Of the OASDI beneficiaries surveyed in 1957 , more than two-thirds of the couples, nearly half of the widows, and one-third of the other aged persons owned their homes, $87 \%$ of which were mortgage free. The median equity in an owned home was $\$ 8,360$ for retired couples, $\$ 6,100$ for single retired workers, and $\$ 8,090$ for aged widows.

In summary, the median value of assets (exceeding debt) held by the OASDI beneficiaries surveyed in 1957 was $\$ 4,920$. Beneficiary couples (both husband and wife entitled to benefits all year) had a median asset value of $\$ 9,260$, single retired workers a median asset value of $\$ x, 270$ and aged widows a median asset value of $\$ 4,380$. Housing of Nonfarm Families, 45 FED. REs. BULl. I097, iI07, irio (1959); White House Conference on Aging, Background Paper on Income Maintenance 16-22, 79-82 (1960); Staff of Senate Special Comm. on Aging, 87th Cong., ist Sess., Basic Facts on the Health and Economic Status of Older Americans 20-23 (Comm. Print 196i).

E Epstein, Money Income of Aged Persons, Mid-196o, Soc. Sec. Bull., Jan. 1961, p. I2. 
$\$ 25$ and $\$ 30$ billion-probably closer to $\$ 30$ billion-for $195^{8}$. By 1960 , the income of persons in this age group had increased by $\$ 2-\$ 3$ billion, as their numbers increased by about 700,000 . Of this total income, slightly more than half came from public income-maintenance programs. Income from employment of persons aged 65 and over totaled between \$Io and \$II billion, and approximately the same amount went to recipients of old-age, survivors, and disability insurance and to retired government and railroad employees. This one-to-one ratio of earnings to benefit payments stands in sharp contrast to the composition of the aged population's income a decade earlier, when aggregate earnings of $\$ 7-\$ 8$ billion amounted to several times as much as benefit payments. In fact, as late as 1958 , earned income ( $\$ 9.5-\$ 10.5$ billion) was significantly larger than benefits ( $\$ 7-\$ 8$ billion) based on previous employment. The increasing proportion of income from benefits reflects both the maturing of the social security system and the secular decline in labor-force participation rates for men. To illustrate the latter: the total number of persons aged 65 and over with paid employment was approximately the same-3 million-in June, $\mathrm{I} 960$ as in June, I950, although the aged population increased in this period by about $3 \frac{1 / 2}{2}$ million. Thus the proportion of this group with any income from current employment dropped from almost one-third to less than one-fourth.

The number of aged persons receiving social insurance benefits based on previous employment (OASDI insurance, railroad retirement, and government employee retirement) increased from 2.7 million in 1950 to $x 1.6$ million in 1960 . Benefits from these three retirement programs rose from slightly over \$1 billion to more than \$10 billion in the same period. Increases in public assistance and veterans' payments to the aged raised the total payments from public income-maintenance programs from $\$ 2.9$ billion at the beginning to $\$ \mathrm{r} 3.8$ billion at the end of the decade. In addition, total income payments from private pensions and deferred profit-sharing plans, plus individual annuities and annuity settlements under life insurance policy proceeds, were estimated to be about $\$ 12 / 3$ billion in $1960 .{ }^{6}$

By the end of $x g 60$, more than seventy per cent of the aged received benefits from OASDI, railroad retirement, or government employee retirement, while only twentyfour per cent had income from current earnings. Of these 4.I million persons with income from employment, 2.3 million men and 900,000 women had paid employment; another 900,000 women were wives of men who were employed. However, only forty-two per cent of the aged men with any work experience worked full-time for a year. In fact, fewer than one in five of all men aged 65 or over (and fewer than one in twenty-five of the women) had full-time jobs. Supplementary income in the form of social insurance benefits, veterans' payments, and in a few cases public assistance, went to almost two-thirds of the aged who received income from employment.?

Withdrawal from the labor force usually results in a sharp drop in family in-

'Id. at 15 .

'Epstein, Money Income Sources of Aged Persons-December 1960, Soc. Sec. Bull, July 1961, pp. 6.9. 
come, despite the cushioning effects of social security or other retirement benefits. One of the clearest illustrations of this decrease can be observed by comparing the medians for the lowest-income spending units in the labor force-those headed by farm operators, whose median income in $195^{8}$ was $\$ 2,800$, and by unskilled and service workers, whose median was $\$ 2,840-$ with the median for spending units headed by retired persons: $\$ 1,630{ }^{8}$ The contrast between the incomes of those aged men who are employed full-time and the incomes of other aged men is even more striking. In I959, the fully employed aged men had a median income of $\$ 3,980$, which was two and one half times that of all other aged men. ${ }^{9}$

In summary, the composition of the aggregate income of the aged has undergone significant changes during the past decade as the proportion of income from current earnings has declined, and the proportion from past earnings has increased. As total OASDI payments continue to increase-because of increases in the numbers of persons eligible, as well as probable increases in the size of benefits-these payments will, of course, assume an even greater relative magnitude, unless there is a reversal of the downward trend of labor-force participation of older men. Such a reversal could come about only if changes occur in the market forces which determine the demand for their services. The factors affecting the propensity of older men to stay in or to rejoin the labor force, and the factors affecting the economy's demand for the labor of this group, therefore, require analysis. After some preliminary data on the age composition of the population and the labor force, the section which follows discusses the reasons for declining labor-force participation rates, leaving to the final section the question of future labor-force activity of older men.

\section{II}

\section{Decline in Labor-Force Participation}

During the first half of the twentieth century the United States' total population almost doubled, and the age composition of the population changed significantly. In particular, the number and proportion of persons $6_{5}$ years of age or over increased from 3 million, or one in twenty-five, in Igoo to almost $12 \frac{1}{2}$ million, or one in twelve, in $1950 .^{10}$ Advance data from the $\mathrm{r} 960$ Census of Population report a total of over I6 $1 / 2$ million in 1960 ; the Social Security Administration believes the number may approach 18 million by January, 1963.11 The proportion of the total population aged

\footnotetext{
${ }^{8}$ Comparison of incomes for different age groups reveals marked differences; the median incomes for spending units in which the head was aged 65 or over was $\$ 1,8_{4}$, whereas the median for all spending units was $\$ 4,440$. The $18-24$ age group, whose incomes were second from the bottom, had a median of $\$ 2,950$, and the $35-44$ age group had the highest median: $\$ 5,730$. 45 Fed. Reserve Butr. 7 13 (1959).

${ }^{\circ}$ Staff of Senate Speciai Comm. on Aging, op. cit. supta note 4, at i8.

${ }^{10}$ U. S. Bureau of the Census, Dep't of Commerce, Census of Population, and Current PopulaTION Reports ser. P.25, No. 66, at X (1952).

"U. S. Dep't of Healith, Education, and Welfare, Social Security Admin., ig6o Population Aged 65 sND OVER (196i).
} 
45 or over increased from eighteen to twenty-nine per cent between 1900 and 1955, to a total of more than 52 million persons, who constitute one-half of the adult population.

The growth in the numbers of older persons, arising from the large number of births and heavy immigration in the past and from increased longevity, is expected to continue throughout the next generation, due to the continued rise in the number of births and some expected increase in longevity. The annual increase in the number of persons 65 and over is now approximately 370,000 and will rise to 500,000 by the end of the century, when the population aged 65 and over will have doubled its present number. However, older persons as a proportion of the total population will level off. Constituting about nine per cent at present, the figure is not expected to exceed ten per cent during the remainder of the century; the number of children is now increasing more rapidly than the number of older people.

\section{A. The Shifting Age Composition of the Labor Force}

Along with the change in the age structure of the population, important changes have also occurred in the age composition of the labor force. Persons aged 45 and over accounted for one-fourth of the working population in 1900; in 1955 the proportion was one-third. During this period the greatest percentage changes occurred in the group $\mathrm{I}_{4}$ to 24 years of age, whose proportion of the labor force declined from thirty-one to less than nineteen per cent, and the group aged 45 to 64 , whose proportion increased from twenty to over thirty-one per cent. ${ }^{12}$ Increases in the latter group reflect the rapid entrance of women into the labor force, particularly since World War II.

Although the number of persons aged 45 and over in the labor force is expected to rise during the $1960^{\circ} \mathrm{s}^{13}$ the long-run decline in labor force participation of men 65 and over will persist. In I8go, two out of three men aged 65 and over were in the labor force, but by $194^{\circ}$ the proportion was two out of five. World War II brought an increased demand for labor and a rise in the participation rates of older men and women; but since the war, participation rates of men have declined sharply. For men 65 and over the rate was fifty-one per cent in 1945 , forty-five per cent in x950, and 36.7 per cent in 1957 . The r 960 rate of 32.3 was less than half of the 1890 rate of 70.0. For women past 65 years of age, the labor force participation rate has increased from 6.7 per cent in 1940 to 9.5 per cent in 1950 and to 10.5 in 1960 . At present, the participation rate for women aged $45-54$ is just under fifty per cent, and the rate for women $55-64$ is about thirty-seven per cent. ${ }^{14}$

On the basis of projections made in 1955, the total labor force is expected to rise by II million in the decade $x 955-65$, for a total of 80 million by 1965 . Because of the

\footnotetext{
19 U. S. Dep't of Labor, Employment and Economic Status of Older Men and Women, Bulz. No. I213, at 5 (I956).

${ }^{23}$ The Department of Labor estimates a labor force increase of $5 \frac{1 / 2}{2}$ million from this age group by I970, bringing the total number of workers aged 45 and over to 33 million. U. S. DeP'T op LABOR, Manpower: Challenge of the I960's I8 (1960).

${ }^{14}$ Stein \& Travis, Labor Force and Employment in 1960, 84 Montmry LABOR Rev. 349 (I961).
} 
sharp rise in the population aged $14-24,4$ million of the increased number will be in this age range. Both the population and the labor force participation rates of men aged 25-44 will remain practically unchanged. For men aged $45^{-6} 4$, population growth will give rise to an increase of $2 \frac{1}{4}$ million workers. But no change in the male labor force aged 65 and over is anticipated; the increase in population will be offset by a continued decline in the participation rate of this age group.

Between 1965 and 1975 , a further increase of $1_{5}$ million is expected to swell the labor force to 95 million. More than 5 million of the increase will come from the under-25 age group. Male workers aged 25-34 will account for an increase of 4 million, and male workers aged $35-44$ for a drop of 600,000 , in accordance with population

TABLE I

Labor Force Participation Rates, by Age and Sex, Actual y955 and Projected rg60-75

\begin{tabular}{|c|c|c|c|c|c|}
\hline Age and $\mathrm{Sex}$ & 1955 & 1960 & 1965 & 1970 & 1975 \\
\hline 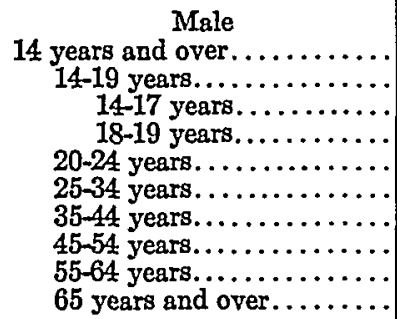 & $\begin{array}{l}82.3 \\
49.0 \\
36.1 \\
76.5 \\
89.5 \\
96.5 \\
96.9 \\
95.1 \\
86.4 \\
38.5\end{array}$ & $\begin{array}{l}80.9 \\
47.9 \\
35.7 \\
75.6 \\
88.1 \\
96.5 \\
96.9 \\
95.1 \\
86.4 \\
36.0^{*}\end{array}$ & $\begin{array}{l}79.1 \\
47.2 \\
34.9 \\
73.7 \\
87.0 \\
96.5 \\
96.9 \\
95.1 \\
86.4 \\
34.0\end{array}$ & $\begin{array}{l}78.4 \\
46.6 \\
34.4 \\
72.6 \\
86.3 \\
96.5 \\
96.9 \\
95.1 \\
86.4 \\
32.2\end{array}$ & $\begin{array}{l}78.4 \\
46.9 \\
34.2 \\
72.1 \\
86.0 \\
96.5 \\
96.9 \\
95.1 \\
86.4 \\
31.0\end{array}$ \\
\hline 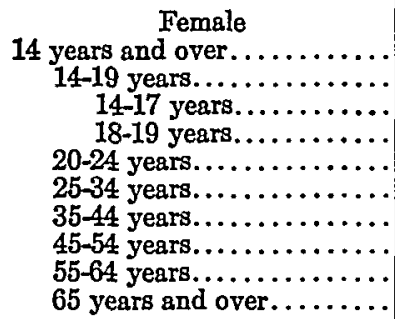 & $\begin{array}{l}34.5 \\
29.7 \\
19.8 \\
50.9 \\
45.8 \\
34.8 \\
41.4 \\
43.5 \\
32.2 \\
10.3\end{array}$ & $\begin{array}{l}36.4 \\
28.6 \\
20.8 \\
46.1 \\
45.4 \\
37.9 \\
43.0 \\
48.2 \\
37.4 \\
11.0\end{array}$ & $\begin{array}{l}37.6 \\
28.2 \\
20.6 \\
44.7 \\
45.3 \\
38.7 \\
45.5 \\
52.1 \\
40.6 \\
11.7\end{array}$ & $\begin{array}{l}38.3 \\
27.8 \\
20.4 \\
43.6 \\
45.2 \\
38.9 \\
47.0 \\
54.5 \\
43.0 \\
12.2\end{array}$ & $\begin{array}{l}38.5 \\
27.9 \\
20.4 \\
42.7 \\
45.2 \\
39.1 \\
47.9 \\
56.0 \\
44.4 \\
12.6\end{array}$ \\
\hline
\end{tabular}

* The actual rate for 1960 vas 32,3. See Stein \& Travis, Labor Force and Employment in 1960, 84 MoNThur LeABor Rev. 349 (1961).

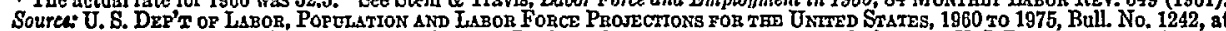
54 (1959); 1955 data from U. S. Bureau of the Census, Dep't of Commerce; $1960-1975$ population from U. S. BuRsav of TeE CeNsus

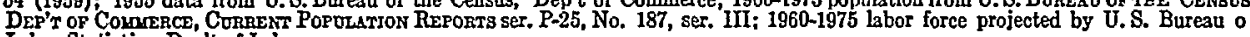
Labor Btatistics, Dep't of Labor.

changes in these two groups. Male workers aged $45-64$ will increase by about $\mathrm{I}^{3} / 4$ million. Finally, the declining participation rate for men $6_{5}$ and over will restrict the labor force increase from this group to 200,000 , despite a rise of $x 1 / 2$ million in their total numbers. ${ }^{15}$

The 1955 projections of labor force participation rates, as shown in table one, predicted a gradual decline in the rate for older men from the actual r955 rate of $3^{8.5}$ to a projected 1975 rate of 3 r.o. However, the I960 actual rate was lower than the I955 study anticipated; instead of the 36.0 projected, the actual rate was 32.3 . In

${ }^{15} U$. S. Dep't of Labor, Population and Labor Force Projections for the United States, ig6o To 1975 , BuLl. No. 1242, at 40-4I (1959). 
fact, largely because of the reduced labor force activity of older men and men under 20, the labor force level for 1960 was lower by about half a million workers than the I955 projection indicated. ${ }^{16}$ The present participation rate for older men is thus almost as low as the rate formerly expected for 1970 . A continuation of the 1955-60 rate of decline would lower the 1965 participation rate for older men to approximately one in four.

\section{B. Reasons for Declining Participation Rates}

The explanation of the long-run fall in the labor force participation of older men requires an analysis of two sets of forces: those factors which affect the rate at which older men offer their services, i.e., the supply of labor; and those factors which influence the rate at which industry hires older workers, or the demand for labor of this age group.

\section{Factors Affecting Supply}

On the supply side, the secular rise in per capita real income has been credited with influencing both the rate of population growth and the propensity of certain groups to join the labor force. The process of industrialization, which is accompanied by rising incomes, urbanization, and-in its early stages-a rapidly falling. death rate, is associated at first with a sharp rise in the population. As both industrialization and urbanization continue, the birth rate is likely to fall and the rate of population growth to slow. Thus, prior to World War II the United States and some of the European countries had undergone such declines in birth rates as to indicate a potential decline in their future populations. Since the war, however, although real income has continued to rise, a reversal of the downward trend in the birth rate has led to an expansion in population, the present rapid growth in the labor force reflecting that upturn in birth rates which began in the early 1940's. In summary, then, the rising real income which earlier supposedly contributed to slowing down the rate of population and labor force growth, has in recent years been accompanied by a rise in fertility rates, and by a growth of both population and labor force.

Examination of the effect of rising income on the propensity of persons to offer their services for hire involves a consideration of the aspirations of the people, and the influence of these aspirations on the different groups making up the labor force. ${ }^{17}$ The desires of the youngest age group for increased education have been met largely as a result of a rising income level, which made possible public subsidies to education. Hence, improved income conditions have clearly contributed to raising the average age of entrance into the labor market. The increase in the labor force participation rates of women may also be due in some measure to rising per capita income, although this supposes that the standard of living is rising even faster than individual income.

${ }^{16}$ Stein \& Travis, supra note 14 , at 349-50.

${ }^{17}$ See John D. Durand, The Labor Force In the United States, 1890-1960, at ro5-09 (1948). 
For older workers, the secular rise in per capita income has been accompanied by a decline in labor force participation, but one may question whether rising income in fact caused the decline. Prior to the era of Social Security benefits, only a very small proportion of the labor force had any retirement income; to the majority of workers, leaving the job, therefore, meant foregoing all income. Moreover, the typical worker, despite a rising wage throughout most of his working life, still held no significant savings at retirement age. For the older worker under these circumstances, his past rising real wage was actually likely to have raised his standard of living and provided incentive to stay in the labor market, rather than providing him with sufficient income to permit retirement.

In considering the extent to which benefits provided retirees under the Social Security Act offer an incentive to withdraw from the labor force, it is important to remember that large numbers of older people have dropped out of the labor market when pensions were extremely small or nonexistent. During the periods I8go-I9ro and r930-34, before social security was enacted, and in 1935-40, when old age assistance was inadequate, participation rates for older workers were declining. It must also be noted that during the r940's, when social security and private pension payments were available, older workers postponed retirement or re-entered the labor force. $^{18}$

Study of the retirement patterns of OASDI beneficiaries has revealed that older persons generally prefer continued employment to retirement on the benefits provided, primarily because the latter are so much lower than the earned income. ${ }^{19}$ In the r940-45 period, less than one-third of the persons aged 65 and over who could have retired with benefits did so. In the latter half of the decade the rate of retirement increased, but in mid-I950 two-fifths of the fully insured were still not drawing their benefits. At the end of June I959, about 2 million of the II.I million eligible persons were affected by the retirement test of the Social Security Act. Of this 2 million, I. 4 million earned over $\$ 2,080$, and therefore received no benefits; 0.3 million earned $\$ 1,20 \mathrm{r}-2,080$ and received partial benefits; and 0.3 million earned $\$ 90 \mathrm{r}-$ $\mathrm{I}, 200$, some of these persons deliberately limiting their earnings to $\$ \mathrm{I}, 200$ in order to receive full benefits. ${ }^{20}$

Further evidence that many older workers would prefer continued work to retirement was provided by a recent study designed to gauge the effect of mandatory retirement policies. A total of I,422 male employees aged 65 were asked whether they preferred retirement at 65 , or continued employment at their present jobs. Forty-one per cent of those workers subject to mandatory retirement at age $6_{5}$ wanted to continue working past 65 ; sixty-one per cent of those subject to mandatory retirement at 68 wished to continue working past 65 ; fifty-nine per cent of those not subject to mandatory retirement at any age wanted to continue working

${ }^{28}$ Clarence D. Long, The Labor Force Under Changing Income and Employment I62-63 (1958).

${ }^{10}$ Wentworth, Why Do Beneficiaries Retire? Who Among Them Return to Work?, Soc. Sec. Bull., May 1955, pp. 3-12.

${ }^{n}$ White House Conference on Aging, Background Paper on Income Maintenance $46-47$ (ig6o). 
past 65 . The majority of the workers who preferred continued employment wanted to work "as long as able." According to the managements of the thirty-one companies involved, two-thirds of the employees who indicated a desire to work past $6_{5}$ were "acceptable for continued employment." More than half of the workers who explained their preference for work over retirement stated that their primary reason was financial. ${ }^{21}$

This explanation for postponing retirement is an obvious one; even with recent increases, OASDI benefits are so low in comparison with earned income that they offer the older man little incentive to withdraw from the labor force. Nor does it seem likely that these benefits, even when combined with the savings and other assets held by the typical worker aged 65 , provide sufficient income to encourage retirement. The older worker's tendency to give poor health as the reason for retirement has prompted the question of whether today's 65-year old man is less healthy and capable of work than the man who reached that age a generation or two earlier. A study focused on the question of whether increased life expectancy is associated with increased ability to work has concluded that "the increased life duration is associated with a better maintenance of muscle strength, and possibly of other functions important to over-all working capacity."22 Studies designed to find some measure of older workers' actual ability on the job include a recent analysis of production workers' comparative job performance by age, which revealed a different pattern for different aspects of job performance. For attendance, no relationship was found; for output per man hour, although there were changes on the average associated with age, there was wide variability about the averages. ${ }^{23}$ Studies of comparative job performance of office workers by age found similar results: relatively little variation in average performance among age groups, but considerable variation among individuals within any one age group. ${ }^{24}$

In summary, there seems to be little evidence that the decline in labor force participation on the part of older men is due to a decrease in their propensity to offer their services for hire. The two major factors influencing their continued participation on the job-improved retirement income and improved health-might appear to be offsetting each other. But retirees' incomes from all sources are still too low to provide any great incentive to leave the job and forego earnings. Explanation of the gradually declining participation rates of men aged $6_{5}$ and over must therefore be sought primarily on the demand side-in the forces which condition the economy's need for older workers and its ability to provide them with productive jobs.

${ }^{21}$ Study made by the National Committee on the Aging, summarized in id. at 57-59.

${ }^{2}$ Simonson, Physical Fitness and Work Capacity of Older Men, 2 Geriatrics 110-12 (1947).

${ }^{23}$ A third aspect of job performance, continuity of service-defined as "the proportion of total workers who remained on the job, i.e., did not quit, get discharged, or retire during a one-year period" showed a lower index for the 65 -and-over age group, largely refiecting retirement. Mark, Comparative lob Performance by Age, 80 Monthly LaBor Rev. I467-71 (1957).

${ }^{2}$ Kutscher \& Walker, Comparative Job Performance of Office Workers by Age, 83 MonthLX LaboR REv. 39 (1960). 


\section{Changes in Demand}

An examination of the changing industrial composition of the labor force may throw some light on the labor demand pattern.

TABLE II

Per Cent Distribution of the Labor Force by Occupational Group, igio-50

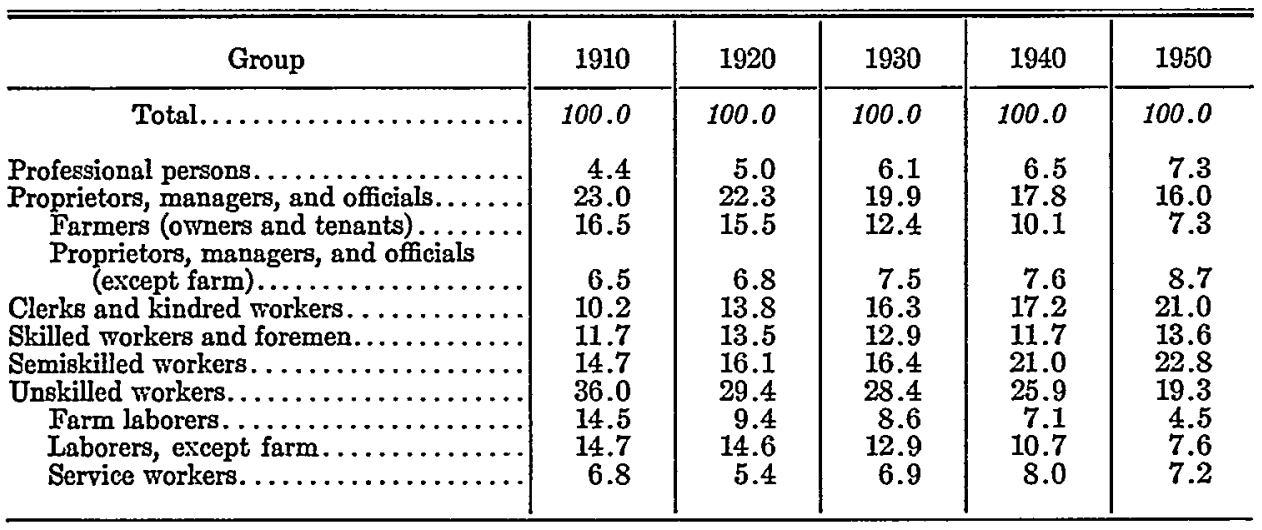

Source: U. S. Bonead of Lapor Statistjes, Dep't of Labor, Emplothent and Econouic Status of Otder Men and Wouren, BoLL. No. 1213, at 17 (1956).

As seen in table two, the major industrial shift has been the movement from agriculture into industry. This shift has brought with it a reduction in the proportion of the total labor force engaged as farm owners and tenants (from 16.5 per cent in rgro to 7.3 per cent in I950) and as farm laborers (from I4.5 per cent to 4.5 per cent in the same period). By contrast, the two occupational groups which have expanded most rapidly have been semi-skilled operatives and clerical and kindred workers. These latter occupations have low proportions of older men employed: in 1956, five per cent of the employed men aged $6_{5}$ and over were employed as clerical and kindred workers, and 9.4 per cent as operatives. Farmers and farm managers, on the other hand, accounted for 25.9 per cent of the employed males aged $6_{5}$ and over. Thus the shrinkage in the relative importance of agriculture has obviously reduced the older man's opportunity for gainful employment.

In addition to the shift out of agriculture, Durand has emphasized that within the non-agricultural sector of the economy, firms tend to grow in size and thus to limit the opportunity for self-employment. He cites the high proportions of selfemployed workers among older men: nearly one-half of the men aged 65-74, and almost two-thirds of the males aged 75 and over were employers and own-account workers, as contrasted with one out of seven in the $25-29$ age group. ${ }^{25}$ He attributes

${ }^{z}$ Long believes that "any affinity between decline in the proportion" of the self-employed and the proportion of elderly men in the labor force has been very weak." As to the effect of inter-industry shifts on the proportion of older workers in the labor force, he concludes that the effect between rgro and 1940 was negligible, since the employee-expanding industries, trade and government, employed as high proportions of older workers as the contracting sector, agriculture. However, in comparing the ratio of elderly workers to workers of all ages, by industry, male workers 45 and over are taken to be elderly. Long, op. cit. supra note $\mathrm{r}$, at 168-73. 
the higher proportion of self-employed older workers partly to shifts from wageearning to entrepreneurial status with age, and partly to the longer span of potential working life for entrepreneurs. ${ }^{26}$

A growth in firm size may affect not only the opportunity for self-employment, but hiring and retirement policies as well. Studies have revealed that the larger the firm, the greater the likelihood of mandatory retirement; ${ }^{27}$ and that the larger firms are also more likely to specify upper age limits in hiring workers. ${ }^{28}$ Thus the older worker's chances of being retained past the age of 65 , or being hired after 45 , appear to be lowered as firm size increases.

In addition to shifts in the industrial composition of the labor force, certain employer and union policies have been cited as important influences on the employment of older workers. From the company's point of view, mandatory retirement, usually at 65 , and a policy of not hiring new employees over 45 years of age, have become necessary corollaries to the growth of private pension plans. The cost of providing an adequate pension for a man hired at the age of 55 is considered prohibitive, and firms are increasingly reluctant to hire workers who have not enough working years left to acquire any significant pension claims. The company also faces the constant pressure for promotion from within the ranks. In the interests of retaining younger employees and providing incentive for the whole work force, company policy has often dictated compulsory retirement.

Intra-plant equity, which would theoretically award promotions on the basis of merit (only one aspect of which is experience), has by many union-management agreements come to be largely equated with seniority rights. A conflict of interest between the young and the older worker, extending to matters other than promotion, is particularly evident during business recessions, when lay-offs occur, and when, in recent years, seniority has given some protection to men in their later working years. The conflict of interest is a constant if less obvious problem in determining retirement policy. Here, seniority rules may have contributed significantly to the development of compulsory retirement policies and, therefore, in providing some security to workers between, say, 45 and 65 , reduced the chances for the 65 -year old retaining his job.

Long-run trends in labor force participation of older men, stemming largely from the secular decline in demand for their services, are, of course, interrupted by temporary increases in demand for all labor, such as occurred during World War II. Similarly, cyclical downturns which increase aggregate unemployment raise the level of unemployment of older workers more than in proportion to their numbers, and for longer periods of time than apply to younger workers. In these short-run fluctuations the older worker is, in short, the marginal worker; he is the

${ }^{\infty}$ DÜAND, op. cit. supra note 12, at 110-12.

" See, for example; Gordon, The Older Worker and Retirement Policies, 83 Monthly Lasor Rev. 577-85 (1960); and Kreps, $A$ Case Study of Variables in Retirement Policy, 84 id. 587-91 (1961).

a U. S. Bureau of Employient Security, Dep't of Labor Bull. No. E-152, at 29-39 (1956), summarized in Stahler, job Problems and Their Solution, 80 Monthly LABor Rev. 22 (1957). 
last to be hired, and the first to be dismissed. The combined effect of these two sets of forces is a secular decline in participation, with short-run fluctuation around the trend. As the short-run pressures have been predominantly downward since the end of World War II, labor force participation rates have fallen more rapidly than was expected under assumed conditions of full employment. These fairly sharp restrictions in the demand for older workers' services have occurred during a period of rapid expansion both in the numbers of older persons and in their proportion of the total population.

\section{III}

\section{Labor Force Participation and the Aggregate}

\section{Demand For Labor}

The question of older men's future labor force participation rates clearly must be posed in the context of the probable aggregate demand for labor. Estimates of the economy's labor needs for, say, 1970 or 1975 , in turn require assumptions as to the rate of economic growth. But while the expected rate of growth is basic to understanding the long-run demand for the services of older people, the growth rate alone is not the whole explanation. Study of growth in the size of total product must be accompanied by study of changes in the composition of that product. A change in the composition of demand for goods may change markedly the aggregate demand for labor, as a result of any one of several movements. Demand may be shifting away from goods requiring large amounts of labor, and toward goods which are produced in almost completely mechanized plants. Or industrial shifts may be occurring which result in the use of less labor of a particular age group; a reduction in the relative importance of farming, cited above, has apparently reduced employment opportunities for older men.

Estimates of future labor force requirements which rely on a straightforward extrapolation of the trend in gross national product, therefore, ignore two important factors: changes in the composition of aggregate demand, and differential rates of productivity increase within the various output sectors. In attempting to incorporate these features, a study currently under way ${ }^{29}$ makes separate projections of income originating in each of the sixty-two sectors of the economy corresponding to the National Income Division industrial classification. Dividing the projected sector income by the projected average output per worker per year, one obtains an estimate of the number of workers which will be required by that sector in the terminal years, on the assumption of a continuation of the present work-week. Aggregation of these individual estimates then yields an estimate of the total labor force needs at the selected future dates. This estimate of the demand for labor

${ }^{\wedge}$ The projections indicated in the remainder of this section are contained in Labor Requirements and Labor Supply, 1970 and 1975, by Juanita M. Kreps, Charles E. Ferguson, and James M. Folsom, which is to be published in 1962 as one of a series of studies in the economics of an aging population. The details of these projections and the statistical methods used are discussed in the larger study. 
is then compared with existing projections of the labor force available for 1970 and I975.

Projections made in the above manner permit tentative conclusions on two important aspects of the future demand for labor: (I) conclusions as to the differential rates of growth both in income and in average output per worker in the different sectors, and hence conclusions regarding the changing industrial composition of employment; and (2) a rough measure of the imbalance between the labor force and the aggregate demand for labor in the selected future dates.

Summarizing the inter-sectoral employment comparison, we find, first, that of the sixty-two industrial classifications, twenty industries are expected to experience declines in employment in the 1959-r970 period (table three). These industries are rather heavily concentrated in the broad classification "Construction and Manufacturing." Agricultural and Extractive Industries, Transportation, and Service Trades

TABLE III

Projected Change in Sector Employment, i959-197o

\begin{tabular}{|c|c|c|c|}
\hline Declining Industries & $\begin{array}{l}\text { Industries Growing } \\
\text { Less Rapidly than } \\
\text { National Average }\end{array}$ & $\begin{array}{l}\text { Industries Growing } \\
\text { at National Average }\end{array}$ & $\begin{array}{l}\text { Industries Growing } \\
\text { More Rapidly than } \\
\text { National Averago }\end{array}$ \\
\hline $\begin{array}{l}\text { Farms } \\
\text { Anthracite Mining } \\
\text { Bituminous and Other } \\
\text { Soft Coal Mining } \\
\text { Food and Kindred } \\
\text { Products } \\
\text { Tobacco Manufactures } \\
\text { Textile Mill Products } \\
\text { Apparel and Other } \\
\text { Finished Fabric } \\
\text { Products } \\
\text { Lumber and Furniture } \\
\text { Products } \\
\text { Products of Petroleum } \\
\text { and Coal } \\
\text { Leather and Leather } \\
\text { Products } \\
\text { Metals, Metal Products, } \\
\text { and Misc. } \\
\text { Machinery, except Elec- } \\
\text { trical } \\
\text { Transportation Equip- } \\
\text { ment, except Auto } \\
\text { Railroads } \\
\text { Local and Highway } \\
\text { Passenger Trans. } \\
\text { Water Transportation } \\
\text { Personal Services } \\
\text { Private Households } \\
\text { Motion Pictures } \\
\text { Amusement and Recrea- } \\
\text { tion, except Motion } \\
\text { Pictures }\end{array}$ & $\begin{array}{l}\text { Metal Mining } \\
\text { Contract Construction } \\
\text { Printing, Publishing } \\
\text { and Allied Industries } \\
\text { Chemicals and Allied } \\
\text { Products } \\
\text { Rubber Products } \\
\text { Stone, Clay and Glass } \\
\text { Products } \\
\text { Electrical Machinery } \\
\text { Wholesale Trade } \\
\text { Retail Trade and } \\
\text { Automobile Services } \\
\text { Security and Com- } \\
\text { modity Brokers, etc. } \\
\text { Real Estate } \\
\text { Services Allied to } \\
\text { Transportation } \\
\text { Telephone, Telegraph } \\
\text { and Related Services } \\
\text { Utilities: Electric and } \\
\text { Gas } \\
\text { Local Utilities and } \\
\text { Public Services, } \\
\text { n.e.c. } \\
\text { Hotels and Other } \\
\text { Lodging Places } \\
\text { Commercial and Trade } \\
\text { Schools and Em- } \\
\text { ployment Agencies } \\
\text { Nonprofit Membership } \\
\text { Organizations, n.e.c. } \\
\text { Federal Gov't. Enter- } \\
\text { prises } \\
\text { Rest of the World** }\end{array}$ & $\begin{array}{l}\text { Agri. Services, For- } \\
\text { estry and Fishing } \\
\text { Nonmetallic Mining } \\
\text { and Quarrying } \\
\text { Paper and Allied } \\
\text { Products } \\
\text { Automobiles and Auto- } \\
\text { mobile Equipment } \\
\text { Banking } \\
\text { Insurance Carriers } \\
\text { Insurance Agents } \\
\text { Highway Freight } \\
\text { Transportation } \\
\text { Air Transportation } \\
\text { Pipeline Transportation } \\
\text { Radio Broadcasting } \\
\text { and Television } \\
\text { Legal Services }\end{array}$ & $\begin{array}{l}\text { Crude Petroleum and } \\
\text { Natural Gas } \\
\text { Finance, n.e.c. } \\
\text { Business Services, n.e.o. } \\
\text { Misc. Repair Services } \\
\text { and Hand Trades } \\
\text { Medical and Other } \\
\text { Health Sorvices } \\
\text { Engineering and Other } \\
\text { Professional Serv- } \\
\text { ices, n.e.c. } \\
\text { Educntional Services, } \\
\text { n.e.c. } \\
\text { Federal General Gov't. } \\
\text { State and Local Gen- } \\
\text { eral Gov't. } \\
\text { State and Local Gov't. } \\
\text { Enterprises }\end{array}$ \\
\hline
\end{tabular}

* Not elsemhere classified.

* Foreign governments and international organitations in which permanent United States residents are cmployed in tho United States. 
TABLE IV

Employment Changes by Broad Industriaz Classification

\begin{tabular}{|c|c|c|c|c|}
\hline \multirow[b]{2}{*}{ Industrial Classification } & \multicolumn{4}{|c|}{ NUMBer of Component INDUSTRIEs Which ARE } \\
\hline & Declining & $\begin{array}{c}\text { Growing Less } \\
\text { Rapidly than } \\
\text { NationalAverage }\end{array}$ & $\begin{array}{l}\text { Growing at } \\
\text { National } \\
\text { Average }\end{array}$ & $\begin{array}{c}\text { Growing More } \\
\text { Rapidly than } \\
\text { NationalAverage }\end{array}$ \\
\hline 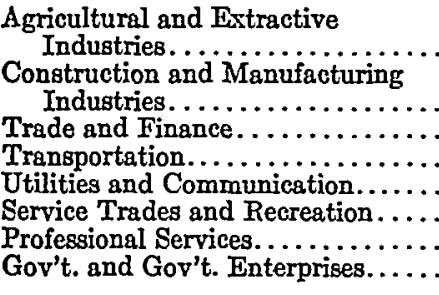 & $\begin{array}{r}3 \\
10 \\
0 \\
3 \\
0 \\
4 \\
0 \\
0\end{array}$ & $\begin{array}{l}1 \\
6 \\
4 \\
1 \\
1 \\
3 \\
3 \\
0 \\
2\end{array}$ & $\begin{array}{l}2 \\
2 \\
3 \\
3 \\
1 \\
0 \\
1 \\
0\end{array}$ & $\begin{array}{l}1 \\
0 \\
1 \\
0 \\
0 \\
\mathbf{2} \\
\mathbf{3} \\
\mathbf{3}\end{array}$ \\
\hline Totals........... & 20 & 20 & 12 & 10 \\
\hline
\end{tabular}

and Recreation account for the remaining sectors in which a decline in the number of full-time equivalent employees is anticipated (table four). Secondly, twenty other industries are expected to experience increases in employment, but at rates that are less than the average rate of increase in employment for the economy as a whole. Again, these industries are relatively heavily concentrated in Construction and Manufacturing, with some representation from all other broad groups except Professional Services. Thirdly, twelve industries scattered throughout the broad industrial classifications are expected to grow in employment at a rate approximately the same as the national average. The Professional Services and Government sectors have only minor representation in this group. Finally, ten industries have employment growth rates in excess of the expected national average, and here the classifications of Government and Professional Services dominate. Furthermore, none of the manufacturing and construction industries are included in this category. These inter-sectoral employment comparisons thus indicate a decline in the relative importance of all the major industrial classifications except Professional Services and Government.

Turning to the question of the overall balance of labor supply and labor requirements, we find that subject to the qualifications specified in the study, the projected rate of unemployment is about eight per cent for 1970 and between 9.5 and ten per cent in I975. Discounting heavily the value of any projection as remote in time as 1975, and considering only the I970 estimate, a review of the growth of unemployment since the end of World War II reveals an upward trend of some significance. A continuation of such a "staircase effect" as we have experienced since I947 makes the possibility of eight per cent unemployment appear less unreal, although no less alarming.

The comparisons afforded by this study are made, of course, with respect to the projected pattern of demand for and supply of all labor; these projections are, there- 
fore, concerned with the employment prospects for older workers only within this context. But the implications for older workers are obvious. The long-run decline in labor force participation rates of older men has been interrupted in recent decades only by the sharp increase in demand for labor created by World War II, after which the rate resumed its downward trend. Furthermore, in the growing residue of unemployment left by the recessions of $1957-5^{8}$ and r960-61, the older worker was particularly prominent. A projection of future labor requirements which falls considerably short of the projected labor supply raises the question of adequate job opportunities for all workers, but the question is of particular significance to the older-and apparently marginal-worker.

Further study is needed to show the relationship between the changing industrial composition of employment and resulting shifts in the demand for labor of particular age groups. If the trend away from employment in construction and manufacturing and into professional services and government continues, will the demand for the services of older workers change relative to the demand for younger employees? It would seem likely that the higher level of education required by the latter jobs would delay entrance to the labor force, and raise the median age of the worker. But it is difficult to tell whether the demand for the services of the man sixty-five or over will be affected.

In the absence of evidence to the contrary, which an analysis of demand for labor by industrial sector and by age group might provide, a continuation of the declining labor force participation rate for older men can be assumed. This assumption is certainly warranted if the level of unemployment continues to rise, and if we accept the general thesis that labor force participation of older men is largely dependent on the demand for their services. Thus the ratio of two out of three older men in the labor force which obtained in 1890 fell to one in three by 1960 , and may fall to one in four by 1965 , and possibly one in five by 1975 .

The prospect of such a continued decline in labor force participation poses important questions regarding the future sources of income for the aged. As their income from current earnings declines, income from public and private pensions will have to be raised, even if the aged are merely to maintain present living standards. And it is doubtful that such a policy of running faster and faster in order to stand still will be wholly acceptable to the aged population. 